УДК 78.071.1(092)Куш:784.4(=161.2)

Юлія Володимирівна Каплієнко-Ілюк

кандидат мистецтвознавства, доцент, доцент кафедри музики Чернівецького національного університету імені Ю. Федьковича докторант Одеської національної музичної академії ім. А. В. Нежданової

yuliyakaplienko@gmail.com

\title{
КАЛЕНДАРНО-ОБРЯДОВІ ПІСНІ В ХОРОВИХ ІНТЕРПРЕТАЦІЯХ АНДРІЯ КУШНІРЕНКА
}

Meта статmi - аналіз обробок українських народних пісень А. Кушніренка та виявлення особливостей його композиторського мислення на прикладі хорових інтерпретацій календарно-обрядових пісень. Методологія. Застосовано методи історико-культурологічного, теоретичного та жканрово-стильового аналізу, що дозволило визначити особливості обробок календарно-обрядових пісень в контексті дослідження музики композитора. Наукова новизна полягає у висвітленні принципів хорових обробок календарно-обрядових пісень, аналізі творів Андрія Кушніренка - буковинського композитора, творчий стиль якого малодосліджений у сучасному музикознавстві. Висновки. Творчість Андрія Кушніренка зразок поєднання фольклору та професійного мистецтва. Композитор створюе високої майстерності обробки, де проявилося власне творче бачення народно-музичних образів у зв'язку з традиціями української професійної школи в галузі обробок народних джерел.

Ключові слова: обробки народних пісень, календарно-обрядові пісні, хорова творчість, композитори Буковини, творчість Андрія Кушніренка.

Kapliyenko-Iliuk Yuliya, PhD in Arts, associate professor, doctoral student of the A. V. Nezhdanova Odessa State Musical Academy

Calendar ritual songs in choral interpretations by Andriy Kushnirenko

The purpose of the article are to analyzes cover versions of Ukrainian folk songs by A. Kushnirenko and reveal the sides of his compositional thinking exemplified by choral interpretations of calendar ritual songs. Methodology. The methods of historical-cultural, theoretical and genre-style analysis were applied, which allowed us to determine the features of the covers of calendar ritual songs while studying the music of the composer. The scientific novelty. In the article the principles of choral covers of calendar ritual songs are highlighted and musical works by Andriy Kushnirenko, a Bukovinian composer, whose artistry has been insufficiently studied in the contemporary musicology, have been analysed. Conclusions. Andriy Kushnirenko's works combine luminous beauty of folklore with professional perfection. The composer creates highly professional covers depict- 
ing his own artistic vision of folk-musical images connected with the traditions of the Ukrainian vocational school, which specializes in covers of folk sources.

Keywords: covers offolk songs, calendar ritual songs, choral works, composers of Bukovina, artistry of Andriy Kushnirenko.

Каплиенко-Илюк Юлия Владимировна, кандидат искусствоведения, доцент, докторант Одесской национальной музыкальной академии им. А. В. Неждановой

Календарно-обрядовые песни в хоровых интерпретациях Андрея Кушниренко

Цель статьи - анализ обработок украинских народных песен A. Кушниренко и выявление особенностей его композиторского мышления на примере хоровых интерпретаций календарно-обрядовых песен. Методология. Применены методы историко-культурологического, теоретического и жанрово-стилевого анализа, что позволило определить особенности обработок календарно-обрядовых песен в контексте исследования музыки композитора. Научная новизна заключается в освещении принципов хоровых обработок календарно-обрядовых песен, анализе произведений Андрея Кушниренко - буковинского композитора, творческий стиль которого малоисследован в современном музыковедении. Выводы. Творчество Андрея Кушниренко - образеи сочетания фольклора и профессионального искусства. Композитор создает высокого мастерства обработки, где проявилось собственное творческое видение народно-музыкальных образов в связи с традициями украинской профессиональной школы в области обработок народных источников.

Ключевые слова: обработки народных песен, календарно-обрядовые песни, хоровое творчество, композиторы Буковины, творчество Андрея Кушниренко.

Актуальність теми дослідження. Серед митців Буковини особливе місце належить Андрію Миколайовичу Кушніренку (1933-2013) композитору фольклористу, педагогу, диригенту, народному артисту України. Його творчість, що тісно пов’язана з вокально-хоровою діяльністю, відзначається високим професіоналізмом та майстерністю. Основна частина його доробку - оригінальні твори для хору і солістів, обробки народних пісень. Кушніренко - автор одноактної народної опери «Буковинська весна», кантати «Молюсь за тебе, Україно», ряду творів для фортепіано і симфонічного оркестру. Він записав більше тисячі народних пісень і мелодій, серед яких більше 100 оброблено для хору та оркестру. Отже, дослідження творчості митця такого рівня стане актуальною темою у сучасному світі національного відродження та сприятиме творчому інтересу з боку науковців та виконавських колективів. 
Аналіз останніх досліджень і публікацій. Діяльність композиторів Буковини недостатньо досліджена. В існуючих підручниках з історії музики розглядаються питання розвитку музичної культури Буковини в контексті загальної характеристики західноукраїнської музики. Проте окремого дослідження культури краю, особливо його сучасних митців, немає у музикознавчій літературі. Джерелом про історію музичної культури й освіти Буковини залишається колективна праця науковців кафедри музики Чернівецького національного університету імені Ю. Федьковича [4]. Життя та творчість А. Кушніренка стали об'єктом дослідження в монографії І. Ярошенко «Мистецтвом встелені шляхи» [7]. Про його виконавську та громадську діяльність $є$ досить багато публікацій у періодичній пресі та довідкових виданнях, в окремих розділах посібників, зокрема в навчальних виданнях «Буковинські композитори» [1], «Хорові диригенти Буковинського краю» [6]. Однак у цих розвідках стиль композиторів Буковини не вивчається, а творчість А. Кушніренка не достатньо досліджена.

Мета дослідження - аналіз обробок українських народних пісень А. Кушніренка та виявлення особливостей його композиторського мислення на прикладі хорових інтерпретацій календарно-обрядових пісень.

Основний виклад матеріалу. У творчості А. М. Кушніренка ключове значення мають обробки народних українських пісень. До них він звертався протягом усього життя, вони стали ознакою його творчого стилю та мають велику художню цінність. Народна пісня була для Кушніренка джерелом натхнення, його стихією, його життям... Саме у збиранні, вивченні та опрацюванні народної пісні він бачив сенс своєї творчості, призначення свого таланту. «Якщо ти любиш свій народ, а Бог дав тобі талант композитора, то будь щедрим, віддай хоч частину його на вівтар розвою рідної народної пісні і виконай свою мистецьку місію - передай цей дорогоцінний скарб для майбутніх поколінь у найдосконалішій художній формі, адже по ньому колись будуть пізнавати рівень культури твого народу, музичний інтелект твоєї нації», - так говорив Кушніренко про своє творче кредо, якого дотримувався у своїй композиторській діяльності $[3,5]$. Ще з раннього дитинства він виховувався в атмосфері народного побуту, де постійно звучали українські пісні, прислухався до мелодій, які лунали у його рідному селі Великі Загайці, що на Тернопільщині. Навчаючись у Львівській державній консерваторії імені М. В. Лисенка, до роботи в галузі обробки народних пісень Кушніренка заохочував його викладач - славетний С. П. Людкевич. 
У коло творчих інтересів Кушніренка потрапляють народні пісні різних регіонів України, серед яких зразки галицького, подільського, буковинського, волинського країв. Так, відомою стала його обробка подільської веснянки «Подоляночка». На даний експеримент маестро наважився теж у студентські роки, внаслідок натхнення, отриманого від вдалої музичної інтерпретації пісні «В кінці греблі шумлять верби». А. Кушніренко із захопленням зазначав: «Окрилений благословенням геніального композитора (С. Людкевича. - Aвт.) я відтоді почав серйозно займатися записами та обробками народних пісень і створенням власних творів. Після того я кожен раз приносив на уроки професору свої обробки - то щедрівку, то колядку, то «Подоляночку»... Він спонукав мене до нових варіантів, які я щораз винаходив і таким чином розвивав свою творчу фантазію. Професор радів, коли мої імпровізації були вдалими і, навпаки, зауважував, коли я вдавався до банальних мелодій і спрощеної їх гармонізації» [3, 6].

Отже, відібравши для своєї обробки «Подоляночку», майбутній композитор розумів, на який ризик він йде. Будучи впевненим у своїх силах, він створює власний варіант відомої пісні, і не помиляється, адже досягає в ній нового рівня музичної інтерпретації, прагнучи виявити й розкрити внутрішні особливості на перший погляд простої народної пісні та розробити власні прийоми ії художнього осмислення. Він зумів показати своє авторське прочитання народного твору. Орієнтуючись на високу культуру акапельного хорового співу та його багатство виражальних засобів, Кушніренко здійснив своєрідну концертну транскрипцію пісні з яскравим авторським тлумаченням iii змісту й образу. Так, просту куплетну форму він збагачує різноманітними прийомами розвитку, що спираються на основи народного багатоголосся та принципи професійного мистецтва. А. Кушніренко у своїх численних обробках, як і в «Подоляночці», намагався відтворити справжній національний колорит української пісні, де народна гармонія складалася, як говорив М. В. Лисенко, «в такій поліфонічній атмосфері, де б кожен голос жив самостійним, окремим повним життям, а вкупі з усіма голосами мусить давати чудовий гармонійний ансамбль... треба не тільки записувати мелодію, особливо ж помічати... усі підголоски; от вони й становлять народний контрапункт» $[5,6]$. Спираючись на традиції та заповіт Лисенка, обробки якого є першими класичними зразками у даному жанрі української музики та становлять виняткову художню та наукову цінність, цей «найдосконаліший контрапункт» Кушніренко покладає в основу своєї об- 
робки. Прагнучи розкрити образність, композитор шукає нові засоби виразності, широко застосовує й класичну композиторську техніку. У результаті твір насичується варіаційними прийомами та, завдяки наскрізному розвиткові й тісному зв'язку музики з текстом пісні, виникає куплетно-варіаційна форма, три куплети якої вкладаються у складну тричастинну однотемну форму. Отже, виникає структура, в якій поєднані ознаки двох видів форм, що вказує на змішану форму «Подоляночки».

Перший розділ форми, як і увесь твір, викладено у соль мінорі, будується на двох строфах народнопісенного тексту, утворює просту двочастинну форму. Перший період складається з 9 тактів та двох речень неповторної будови (4 т. +5 т.). Тема пісні починає звучати в одноголосному викладі сопрано, лише у третьому такті до них приєднується підголосок альтів, хроматизми якого розсвічують мелодію новими ладовими барвами. Виклад усього періоду доручається лише жіночим голосам, викликаючи асоціації з дівочими весняними танками пошуку подоляночки. Другий період простої форми, що складається також з двох речень (4 т. +5 т.), демонструє новий тип фактури, де до ознак гетерофонії приєднуються елементи імітаційної поліфонії. Гармонічний план другого речення, початок якого заснований на чергуванні акордів подвійної домінанти й домінанти основної тональності, у той же час демонструє ознаки народного гуцульського або думного ладу з його IV й VI підвищеними ступенями; наступні такти збагачують гармонію новим тональним розвитком з відхиленнями у паралельний мажор та субдомінанту основного соль мінору. Завершення розділу накладено на початок середини складної тричастинної форми, яка побудована на такому ж тематичному матеріалі, що й перший розділ. Однак поетичний текст набуває певного розвитку, а за ним й музика зазнає важливих змін. Середній розділ вкладається в просту двочастинну форму, в якій перший період розширено до 11 тактів за рахунок доповнення у першому реченні. У даному куплеті подається новий варіант поліфонічної обробки початкового мелодичного наспіву, де композитор експериментує зі вступами голосів: почергово доручає низхідний хроматизований підголосок тенорам та альтам, у третьому такті першого речення додає басів з імітацією основної теми в тональності субдомінанти. Окрім того, вже на початку Кушніренко вносить ознаки ладової перемінності з варіантним III ступенем, чим підкреслює народність мелодико-гармонічного розвитку. Друге речення першого періоду середини демонструє нові 
прийоми обробки народної пісні. Тут на перший план знову виходять сопрано, остинатна мелодія яких розцвічується витриманими звуками інших голосів на mormorando. Складні гармонічні вертикалі, серед яких зменшені септакорди, акорди подвійної домінанти, побічні домінанти, по-новому забарвлюють та розробляють тему пісні.

Наступний, другий період середньої частини форми - кульмінація пісні. На даному етапі обробки композитор використовує різні види фактури: гомофонно-гармонічний, підголосково-поліфонічний та імітаційний виклад. Починаючи тему в октавному дублюванні альтів басовою партією, в розвиток вводяться октавні підголоски інших голосів, що призводить до tutti паралельними октавами. Такого роду паралелізми характерні для народного типу багатоголосся. Динамічній напрузі даного такту сприяє і використання підвищених IV та VI ступенів, які тут сприймаються ще більш виразно та спричиняють інтонаційне переродження початкової теми. Подальший розвиток заснований на акордово-гармонічному складі фактури і вносить ознаки паралельно-змінного ладу, що проявляється у підкресленому звучанні акордів паралельного сі-бемоль мажору. Хроматизований нижній голос диктує гармонічний план побудови: гармонічна нестійкість, використання еліптичних зворотів призводять до несподіваних тональних зрушень, в основі яких домінантові ланцюжки акордів (E-A-D). Незважаючи на активність тонального розвитку, усе повертається в межі основної тональності та ії паралелі. Кульмінація досягає свого апогею в останньому такті середнього розділу, де гучні акордові вертикалі, які ущільнюються розшаруванням чоловічих партій, завершуються колоритними, суто народними октавами з варіантним закінченням на квінтовому тоні мінорного ладу. Така варіантність каденцій була вдало застосована композитором, як підкреслення народного походження пісні.

Третій куплет - скорочена реприза складної тричастинної форми, побудована на тематичному матеріалі першого періоду простої двочастинної форми. Динаміка, як і увесь розвиток розділу, поступово згасає. Однак, незважаючи на це, реприза не позбавлена індивідуальності та розвитку, адже в ній спостерігаємо й нові поліфонічні прийоми (обернений дзеркальний контрапункт підголоску, який раніше був заснований на низхідному хроматичному русі, а тепер змінює напрямок на висхідний), й імітацію, подібну до імітації в середині, але тепер основну тематичну ланку підхоплюють не баси, а тенорова партія та ще й не в тональності субдомінанти, а в паралельному сі-бемоль 
мажорі. Перше речення періоду завершується ще однією варіантною каденцією, на цей раз акордом увідної подвійної домінанти сі-бемоль мажору, з якого й починається поступове завмирання. В заключному реченні репризи останній раз проявляються ознаки імітаційної поліфонії, робиться спроба динамічного посилення з досягненням мелодичної вершини, підкресленої акордовим викладом. Проте останні такти пісні поновлюють інтонації народної веснянки, які ніби розчиняються на фоні витриманих звуків інших голосів хорової фактури, де нижній утримує тонічний органний пункт, а середні голоси утворюють низхідний рух паралельними терціями. Завершується обробка світлим звучанням акорду мажорної тоніки.

Отже, даною обробкою відомої народної пісні А. Кушніренко продемонстрував свій неабиякий хист, майстерну композиторську техніку, вміння зануритись у глибинні можливості народної пісні, виявити іiї приховану художню цінність, народний колорит та автентичну красу.

Серед календарно-обрядових пісень, оброблених А. Кушніренком, можна виділити обжинкову «Ой на горі там женці жнуть», мелодія якої була записана С. Воробкевичем для мішаного хору а'cappella. Пісня написана у куплетній формі, в якій куплет повторюється три рази з різним текстом. В основу кожного куплету покладено трирядкову строфу, де перший рядок повторюється двічі. Таким чином, утворюється форма періоду з двома контрастними реченнями, 8 та 12 тактів, у середині яких покладено принцип варіаційного повторення фраз. Отже, незважаючи на використання звичайної куплетної форми, автор обробки прагне уникнути статичності хорового викладу, тому застосовує варіаційний принцип у середині куплету, а не між куплетами усієї форми.

Характер музики цієї пісні відрізняється розспівністю, величністю. Кожна строфа завершується унісонним викладом верхніх голосів на домінанті основної тональності (ля мінор), що підкреслює народний колорит. Починається тема жіночими голосами, які виконують мелодію з терцієвим дублюванням, іiі поступово підхоплюють інші голоси. Розвиток цього твору підпорядковано певному задуму автора, що полягає в «бажанні досягти стереофонічного звучання голосів за рахунок використання засобів імітаційної поліфонії, де окремі голоси ведуть канон, що відображає безперервну ходу женців до господаря після обжинків останнього снопа, які «у село вертають і пісні співають, що аж гай гуде» [3, 12]. Отже Кушніренко використовує багатство виражальних засобів, насичуючи музичну мову вираз- 
ними та цікавими деталями. Так, кожне речення куплету будується за принципом початкового та похідного сполучення голосів хору, де автор застосовує різні види поліфонічної техніки, зокрема канонічну імітацію в першому реченні та горизонтально-рухомий контрапункт у другому, чим демонструє свою власну майстерність та різноманітність художніх вирішень.

Незважаючи на камерність обробки даної пісні, вона відрізняється оригінальністю гармонічної мови та прийомів голосоведіння, які переходять з народної виконавської практики в професійну. У цій мініатюрі можна віднайти й унісонно-октавні виклади, й неповні акорди, й паралелізми досконалих консонансів та секстакордів побічних тризвуків, й народні лади з перевагою гармонічного та мелодичного видів мінору.

Отже, народна пісня «Ой на горі там женці жнуть» в обробці А. Кушніренка - зразок витонченого твору камерного типу, де ювелірно відпрацьовані всі інтонаційні можливості народного джерела, яке розквітло новими барвами завдяки сміливим композиторським рішенням автора.

Працюючи $з$ колективом Державного заслуженого академічного Буковинського ансамблю пісні і танцю України, Андрій Миколайович Кушніренко складав та обробляв різноманітні вокально-хореографічні композиції, серед яких можна виділити уривок 3 «Щедрого вечора» - Щедрівки. У цій хоровій обробці композитор відтворив картину народного новорічного свята, де змальовується сцена колядування. Кушніренко створює високої майстерності вільну обробку, де поліфонічно поєдналися наспіви відомих народних щедрівок. Розгортаючи розмаїту обрядову картину, автор поєднує контрастні плани, де одночасно звучать три хорові гурти, які співають кожен свою щедрівку: «Ой сивая та і зозуленька», буковинську маланчину пісню «Наша Маланка» та відомий наспів «Щедрика». Таке поєднання контрастних планів - різних груп колядників - має свої традиції, започатковані ще М. В. Лисенком, який своїми «Колядками та щедрівками» втілив особливо цікавий задум, що був високо оцінений молодшим поколінням українських митців, зокрема К. Стеценком, О. Кошицем, С. Людкевичем [2, 55]. Окрім того, сцени колядування цікавили багатьох композиторів. Так, наприклад, П. Козицьким було створено одну з його найбільш відомих обробок «Ой коляда, колядниця», в якій передається весела, грайлива та жвава картина народного свята $[5,12]$. 
В хоровій сюїті «Щедрівки» використовується принцип поліметрії, де три хори виконують щедрівки у різних метричних розмірах (4/8 та 3/8). Незважаючи на таке складне вертикальне сполучення, контрастні поліфонічні пласти синхронно зливаються в єдиному гармонічному потоці. А. Кушніренко так пояснює принцип, яким він керувався при створенні подібної композиції: «Тут засобами контрастної поліфонії відтворюється інсценізоване театральне дійство, де хористи повинні не лише виконувати свої хорові партії, а й проявляти артистизм і бути безпосередніми учасниками цього дійства, де сходяться щедрівники з різних куточків одного села з своїми атрибутами та різними щедрівками, відтворюючи картину зимового новорічного свята» $[3,12]$. За таким же принципом А. Кушніренко створив ще одну композицію - фрагмент «Буковинського весілля», де застосовує «антифонне звучання трьох весільних пісень: «Із-за гори ясне сонце» - коли дружки вбирають молоду до шлюбу, «Надобридень, молода» - коли молодий із подарунками в супроводі дружбів іде на зустріч з молодою, «Ой, упала зірка ясна» - де свашки своїми коломийками вихваляють молодого» [3].

Обробка «Щедрівок» вкладається у три розділи своєрідної поліфонічної форми з наскрізною будовою. Мелодії пісень вступають почергово, створюючи ефект стереофонічного звучання, в якому поєднуються співи трьох груп колядників: жіночий гурт - перший хор, що утворюється з сопрано та альтів, чоловічий колектив - другий хор, в який входять тенори з басовою партією, та знову жіночий гурт - третій хор, що складається лише з сопранової партії. Перший розділ цілком побудовано на викладі першої щедрівки, яка розпочинається з унісонного викладу сопрано і альтів, тільки на словах «щедрий вечір, добрий вечір» з'являється терцієва втора, що характеризує типовий народний вид багатоголосся. Перший куплет пісні викладено у гармонічному соль мінорі, у розмірі 3/8, у швидкому темпі з характерним народнопісенним закінченням з ферматою на передостанньому складі та коротким завершальним звуком. Наступний розділ усієї форми починається з другого куплету першої щедрівки, але вже $з$ другого такту відбувається стретне напластування хорових колективів, де в розмірі $3 / 8$ починає звучати друга щедрівка «Наша Маланка», яку стримано та наспівно виконує хор чоловіків. Складне поліметричне сполучення у цілому не дисонує, хори не заважають один одному, а утворюють логічну функціональну вертикаль, засновану на однотональному гармонічному розвитку. Цей розділ компо- 
зиції завершується виконанням другої щедрівки, заключна тонічна квінта якої накладається на появу третього гурту з «Щедриком». Сопрано виконують мелодію щедрівки, яка у наступному, заключному розділі форми виконує функцію сопрано-остинато, а її звучання нагадує виконання пісні дитячим колективом. Таким чином, третій розділ об'єднує усі три хори в контрапунктичному звучанні, ніби згуртовує спів різних груп колядників. Вступ хорів усієї композиції виявляє ознаки концентричності, де після почергового вступу трьох колективів спостерігається їх дзеркальне повторне звучання (I хор - II хор III хор - II хор - I хор). Останній розділ - найбільш динамічний $(f$ та $m f$ ), його відрізняє контраст типів вокальної декламації, що проявляється в наявності речитативних вигуків третього хору на словах «3 Новим роком, з новим щастям...» на фоні мелодекламації інших хорових гуртів. Привертає увагу наявність у третьому розділі ознак політональності: перший і другий хори виконують свої щедрівки у соль мінорі, а мелодія «Щедрика» звучить у ре мінорній тональності. Проте такий тональний контраст не вносить дисонансу, а навпаки, підкреслює народний колорит звучання з характерними ладовими особливостями, адже другий ступінь ре мінору виконує роль шостого високого у соль мінорі, та з підкресленим значенням квінти ладу, яка нерідко бере на себе ознаки тонічного устою. Кінець композиції побудовано на органному пункті у вигляді тонічної квінти, на фоні якої впевнено закріплюється звучання трьох хорів.

Отже у даній композиції, що передає загальний емоційний тонус та різнобарвність народних щедрівок, А. Кушніренко став гідним продовжувачем здобутків та ідей М. Лисенка, поєднуючи найкращі зразки фольклору з надбаннями професійного мистецтва.

Висновки. Отже, серед обробок народних пісень у творчому доробку Кушніренка яскравою оригінальністю відзначаються його хорові інтерпретації календарно-обрядових пісень. У цих композиціях проявилися стильові риси творчості Кушніренка - одного з сучасних майстрів жанру обробок народної пісні. Скориставшись надбаннями корифеїв української композиторської школи, таких як М. Лисенко, М. Леонтович, С. Людкевич, буковинський композитор збагатив хорову літературу сучасними зразками власних інтерпретацій народних мелодій та здійснив вагомий внесок в принципи роботи з фольклорним матеріалом, застосувавши складні поліфонічні прийоми розвитку у тісному зв'язку з національними, зокрема буковинськими, джерелами та особливостями народного багатоголосся. 


\section{СПИСОК ЛІТЕРАТУРИ}

1. Буковинські композитори: навч. посібник / уклад. А. В. Плішка. Чернівці: Чернівецький нац. ун-т, 2011. 143 с.

2. Історія української музики: у 6 т. / відп. ред. М. П. Загайкевич. Київ: Наук. думка, 1990. Т. 3: Кінець ХІХ - початок XX ст. 464 с.

3. Кушніренко А. М. Співаночки мої любі: авт. збірник вокально-хорових творів / заг. ред. та муз. упорядкування А. М. Кушніренка. Чернівці: Чернівецький нац. ун-т, 2011. 180 с.

4. Кушніренко А. М., Залуцький О. В., Вишпінська Я. М. Історія музичної культури й освіти Буковини: навч. посібник. Чернівці: Чернівецький нац. ун-т, 2011. $376 \mathrm{c.}$

5. Луговенко В. М., Ніколаєва Н. М. Українська хорова література. Київ: Муз. Україна, 1985. 62 с.

6. Хорові диригенти Буковинського краю: довідник-посібник / уклад. А. В. Плішка. Чернівці: Рута, 2008. 81 с.

7. Ярошенко I. В. Мистецтвом встелені шляхи. Андрій Кушніренко - диригент, композитор, педагог. Чернівці: Прут, 2004. 220 с.

\section{REFERENCES}

1. Plishka A. V. (2011). Bukovinian composers. Chernivtsi: Chernivetskiy nats. un-t [in Ukrainian].

2. Zagaykevich M. P. (Eds.). (1990). History of Ukrainian music (Vol. 3). Kyiv: Nauk. Dumka [in Ukrainian].

3. Kushnirenko A. M. (2011). Spivanochky my dear. Chernivtsi: Chernivetskiy nats. un-t [in Ukrainian].

4. Kushnirenko A. M., Zalutskiy O. V., Vishpinska Ya.M. (2011). History of musical culture and education of Bukovina. Chernivtsi: Chernivetskiy nats. un-t [in Ukrainian].

5. Lugovenko V. M., Nikolayeva N. M. (1985). Ukrainian choral literature. Kyiv: Muz. Ukraina [in Ukrainian].

6. Plishka A. V. (2008). Choir conductors of Bukovina region. Chernivtsi: Ruta [in Ukrainian].

7. Yaroshenko I. V. (2004). The art is covered with paths. Andriy Kushnirenko conductor, composer and teacher. Chernivtsi: Prut [in Ukrainian].

Стаття надійила до редакиії 15.03.2017

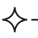

